\title{
Archaeological Testing of Resources Within the Shafter Historic Mining District US Highway 67, Presidio County, Texas
}

John W. Clark Jr.

Follow this and additional works at: https://scholarworks.sfasu.edu/ita

Part of the American Material Culture Commons, Archaeological Anthropology Commons, Environmental Studies Commons, Other American Studies Commons, Other Arts and Humanities Commons, Other History of Art, Architecture, and Archaeology Commons, and the United States History Commons

Tell us how this article helped you.

This Article is brought to you for free and open access by the Center for Regional Heritage Research at SFA ScholarWorks. It has been accepted for inclusion in Index of Texas Archaeology: Open Access Gray Literature from the Lone Star State by an authorized editor of SFA ScholarWorks. For more information, please contact cdsscholarworks@sfasu.edu. 


\section{Archaeological Testing of Resources Within the Shafter Historic Mining District US Highway 67, Presidio County, Texas}

\section{Licensing Statement}

This is a work produced for the Texas Department of Transportation (TxDOT) by the report producer. TxDOT and the report producer jointly own all rights, title, and interest in and to all intellectual property developed under TXDOT's contract with the report producer. The report may be cited and brief passages from this publication may be reproduced without permission provided that credit is given to both TXDOT and the report producer. Permission to reprint an entire chapter, section, figures or tables must be obtained in advance from either the Supervisor of the Archeological Studies Branch, Environmental Affairs Division, Texas Department of Transportation, 125 East 11th Street, Austin, Texas, 78701 or from the report producer. 
ARCHAEOLOGICAL TESTING OF RESOURCES

WITHIN THE SHAFTER HISTORIC MINING DISTRICT

US HIGHWAY 67, PRESIDIO COUNTY, TEXAS

By

John w. Clark, Jr. 


\begin{abstract}
Improvements to US 67 in Shafter, Presidio County, Texas, will affect three cultural areas within existing or proposed right-of-way. These areas include (1) a small early twentieth century dump designated Site 41PS344, (2) Site 41PS109 which comprises two small associated historic structures, and (3) a relatively recent concrete slab. Site 41PS344 lies to the southwest and outside of the Shafter Historic Mining District, while Site 41PS109 and the concrete slab are located within the boundaries of the Historic District. Testing operations to determine the eligibility of these sites on an individual basis for inclusion within the National Register of Historic Places were undertaken in August 1981. Testing operations consisted of surveying the right-of-way area, mapping, and test excavations. The small dump and the concrete slab proved to be of no archaeological or historical significance and do not meet the criteria for inclusion within the National Register of Historic Places. Site 41PS109 consists of a structure built of masonry rubble which contains an archaeological deposit up to $80 \mathrm{~cm}$ in depth within its walls and does meet the criteria for inclusion within the National Register of Historic Places. Full excavation and documentation of this structure is recommended. The associated feature comprising Site $41 \mathrm{PS} 109$ is a dugout excavated into limestone bedrock.
\end{abstract}




\section{INTRODUCTION}

The town of Shafter, in Presidio County, Texas, was founded in 1881 by a mining company comprised of Willi a m B. Shafter, W. S. Noyes, Lt. John

L. Bullis, and John W. Spenser and called the Presidio Mining Company. Through the early 1900s the mines increased production and capacity yielding silver, lead, and a small amount of gold. The vast majority of the maximum of 300 mine workers were Mexicans and Mexican-Americans. The company provided a club house, hospital, boarding house, and houses for the miners. Labor problems plagued the endeavor and a depression hit the town in 1931 when the price of silver dropped. The mines were closed, leaving some 300 families out of work. The mines opened briefly under the New Deal, but were closed again in 1942 due to labor problems, lowering of the grade of silver recovered, depletion of the silver reserves, and some flooding in the mines. The mines were again re-opened in 1981-1982 and considerable earth-altering activities are taking place at the present time.

At present, portions of US 67 between Marfa and Presidio consist of 22 ft.-wide pavement with many horizontal and vertical curves which seriously impair sight distances. The portion of the reconstruction project in Shafter involves widening the pavement to $24 \mathrm{ft}$. and the addition of 6 ft.-wide shoulders. Improvements include flattening vertical curves, realignment of horizontal curves, and the addition of passing lanes where feasible. No additional right-of-way will be acquired for the project within the Shafter Historic Mining District.

In August of 1975 a National Register of Historic Places Inventory-Nomination Form was submitted by the Texas Historical Commission to the Keeper of the National Register designating the town of Shafter, Presidio County, Texas, as the Shafter Historic Mining District. The Shafter Historic Mining District was subsequently included in the National Register of Historic Places. The Shafter mines themselves were not included within the Historic District because of their distance from the town. An on-site historical-archaeological survey of the proposed 
highway project was conducted by a member of the State Department of Highways and Public Transportation (SDHPT) professional cultural resources staff on May 25, 1976, under the auspices of Procedures for the Protection of Historic and Cultural Properties (36 CFR, Part 800).

Archaeological testing and mapping of areas within the highway right-ofway in Shafter were conducted on August 19 and 20, 1981, under the direction of John W. Clark, Jr., of the SDHPT professional cultural resources staff. Work performed included a detailed pedestrian survey of the right-of-way, mapping of features encountered, detailed mapping of two structures, and archaeological testing of the structure containing intact deposits.

The object of the testing operations was to determine whether those features lying within the right-of-way meet the criteria of eligibility for inclusion within the National Register of Historic Places, to determine the nature of the deposits and features, and to determine the cultural context and archaeological/historical significance, if any, of those sites investigated. Testing operations were carried out under the auspices of Procedures for the Protection of Historic and Cultural Properties (36 CFR, Part 800), procedures prescribed and endorsed by the Fede ral Highway Administration.

The Shafter Historic Mining District is located along the floor and flanks of the low canyon of Cibolo Creek adjacent to and crossing US 67, approximately 20 miles north of Presidio in Presidio County, Texas (Fig. 1 ) From the US 67 bridge, the creek flows to the southeast to a vertical cut made by the creek in the mountain massif. From there it flows due west to another steep rock bank and turns south.

Southwest of the US 67 bridge are two adobe structures and a group of ruins associated with the National Guard Camp established in 1916 to protect the area from border raids. The most heavily occupied structures are located east of US 67 in the loop formed by the creek flowing southeast and then west (Fig. 1). A mong these structures are some of 
This Page Redacted Per THC Policy 
obviously modern construction. South of the westward-flowing portion of Cibolo Creek and east of the southward-flowing portion are currently occupied stone and adobe structures and a substantial number of ruins including the smelter facilities. There are 45 historic structures in excellent condition, most occupied by Mexican-American families.

In all areas of the District, especially the south end, are ruins of stone and adobe buildings. The ruins range from simple stone alignments around the former National Guard tents to ruined stone and adobe houses and even major abandoned structures such as the smelter and the hospital. 


\section{TESTING OPERATIONS}

Archaeological testing and mapping were conducted in the US 67 highway right-of-way at the community of Shafter, Presidio County, Texas, on the 19th and 20th of August, 1981. This work was done in connection with the widening of the highway within the existing right-of-way in the Shafter Historic Mining District and the straightening of a curve immediately to the southwest of the Historic District requiring the acquisition of new right-of-way. Three locations within the existing or new right-of-way were determined to contain evidence of cultural remains. These are (1) a small early twentieth century dump which has been designated as Site 41PS344, (2) Site 41PS109 which comprises two small associated structures, and (3) a relatively recent concrete slab (Fig. 1).

In an area immediately to the southwest of the Historic District where new right-of-way will be acquired to straighten out an existing curve, a small scattered dump was observed lying on the west side of the present highway. This site has been recorded at the Texas Archeological Research Laboratory of the Balcones Research Center, The University of Texas at Austin, and has been designated Site 41PS344. The dump site covers an area of approximately 0.25 acre with cultural material lying scattered on the exposed bedrock. Observed cultural debris included tin cans, condensed milk cans, a ceramic door knob, a variety of broken bottles, and American and European ceramics, as well as a small number of complete bottles.

A collection was made of those items which could provide information about the date of this dump, including bottle fragments with makers' marks, ceramic fragments with makers' marks, decorated ceramic fragments, and bottle necks with mold seams. Bottle manufacturers' marks included such common marks as Owen's Illinois and Hazel-Atlas, and the less common mark of the Cartel Vidriera de Monterrey established in 1912.

There were a small number of pre-World War I bottle sherds and several post-1914 bottles. It can be assumed that the date for the dump is 
circa 1915. Since the dump is lying on exposed bedrock, there is no stratigraphic sequence to be determined.

Site 41PS109 is located within the Shafter Historic Mining District, lying within the existing highway right-of-way to the west of the existing roadway. It is comprised of two features, (1) a masonry structure consisting of a single room and constructed of roughly coursed, double wall rubble masonry with rubble fill and mud mortar, and (2) a dugout excavated into the bedrock (Fig. 2).

The masonry structure measures approximately 3.5 by 4.2 meters (exterior dimensions with $60 \mathrm{~cm}$-thick walls). Stones comprising the walls are limestone and sandstone. Oriented north-northeast to south-southwest, the ruin contains a deposit of $80 \mathrm{~cm}$ in depth, consisting of collapsed wall rubble. With the exception of the remains of a sheetiron, wood-burning stove, artifacts recovered from these deposits were originally included within the mud mortar. These consisted of glass and ceramic fragments which are well broken.

A test pit was placed in the interior southwest comer of the ruin in order to determine the depth of the fill and to locate the floor of the structure (Fig. 3). This fill was excavated in small increments by trowel in the hope of distinguishing any natural levels. It was found that the undifferentiated deposit lay on a natural, leveled bedrock floor and that the interior walls of the structure had been plastered with mud and whitewashed. The remains of a sheet-metal, woodburning stove were recovered from this test pit (Fig. 4). This stove was affixed to the bedrock by means of spikes. Figure 5 shows profiles of the west and south walls of the test unit in the limestone masonry structure.

To the north of the masonry structure is a dugout excavated into an outcrop of highly jointed, thinly bedded limestone (Fig. 2). Use was made of natural joint fracture planes in the construction of this feature. The remains measure 3.5 by 4.5 meters (interior measurements). The 


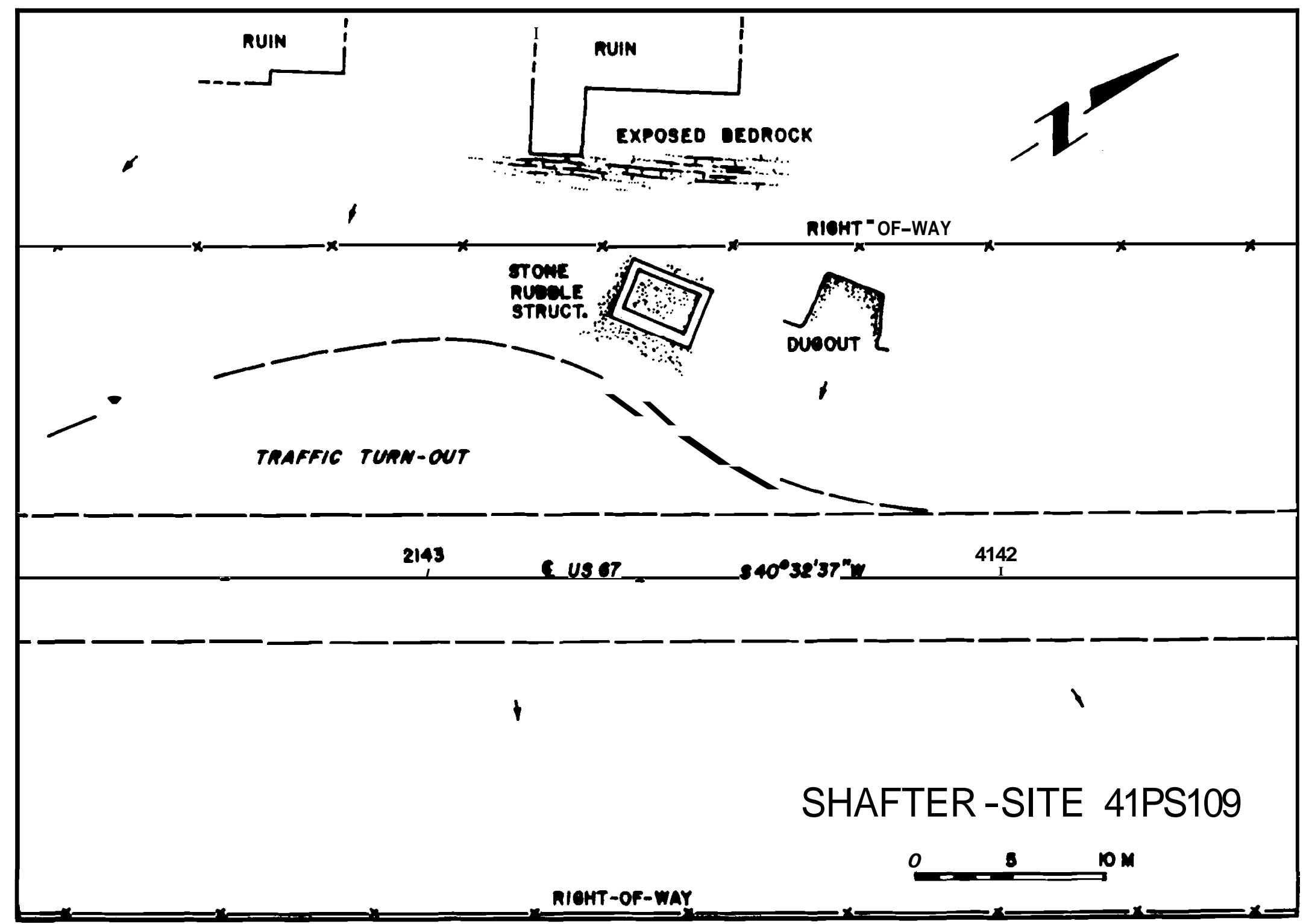

FIGURE 2. Site 41PS109. 


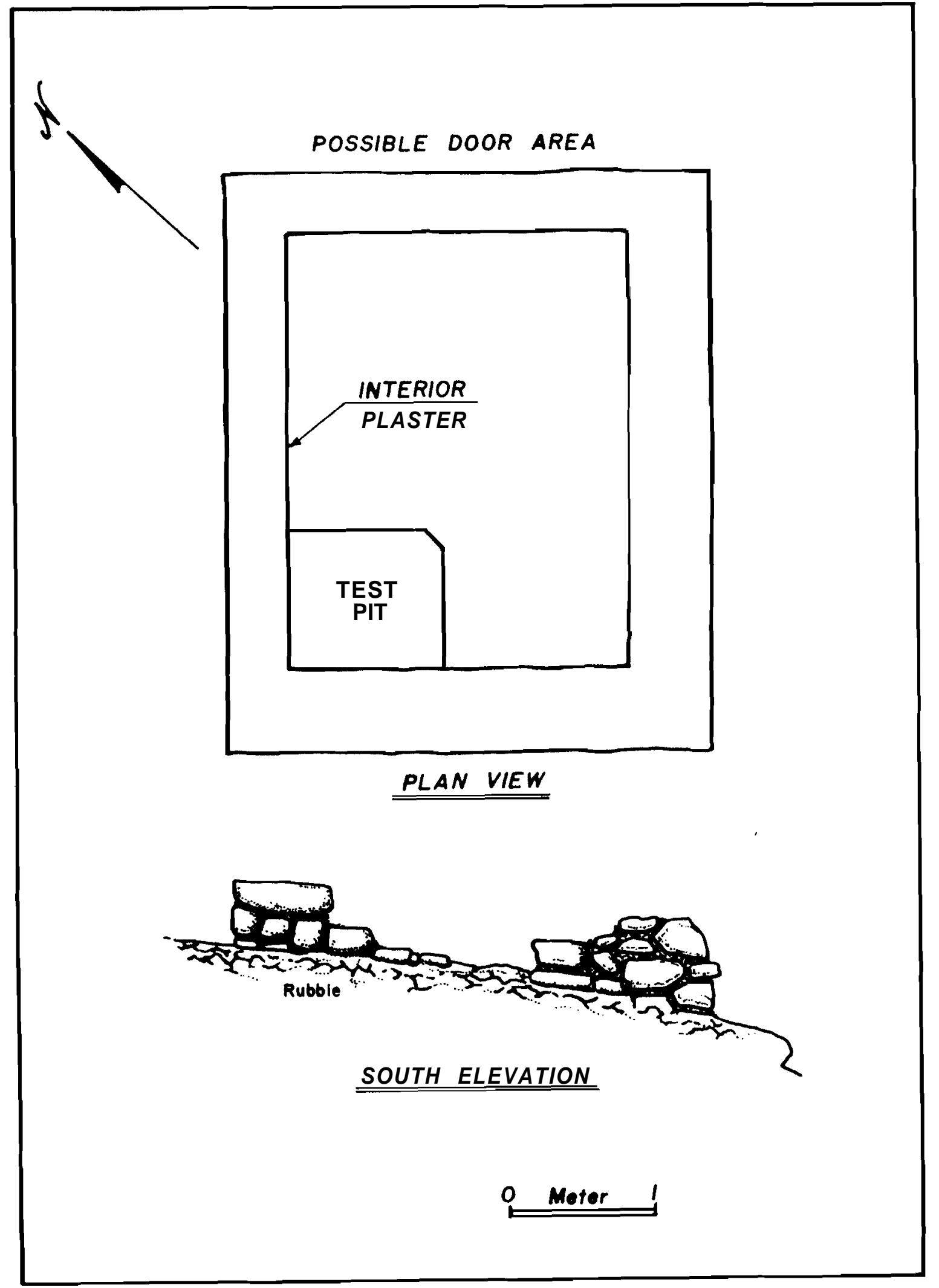

FIGURE 3. Limestone masonry building at Site 41PS109. 


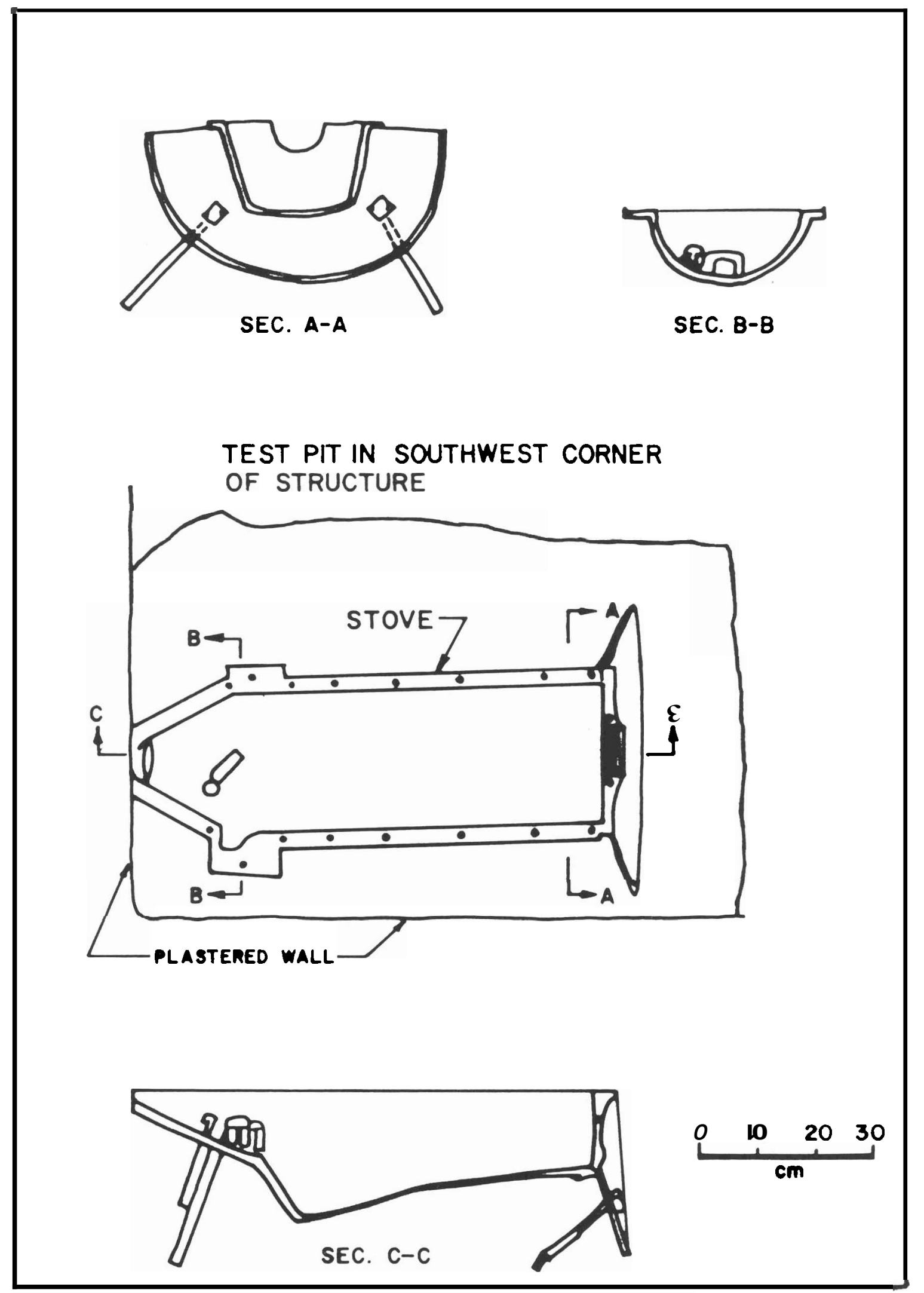

FIGURE 4. Plan view of test pit showing stove in place. 


\section{TEST PIT PROFILES}

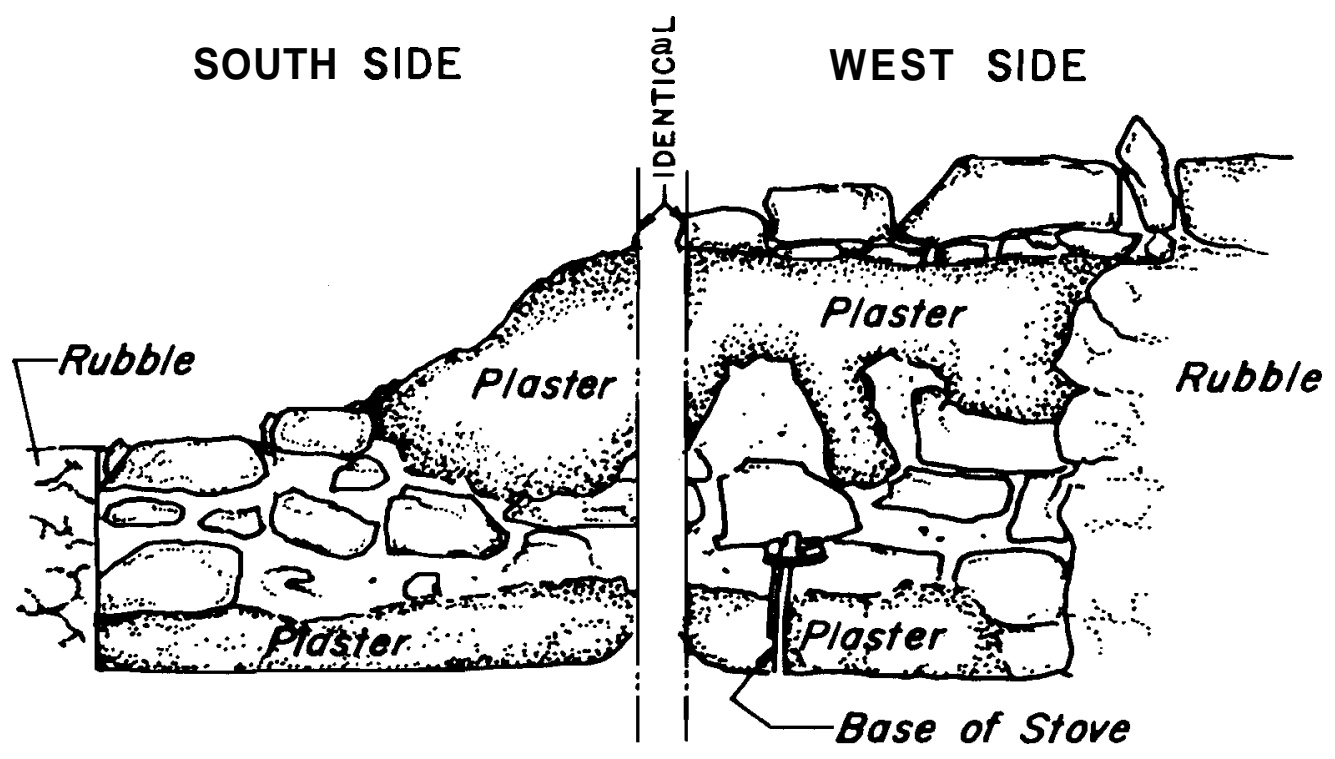

Floor on Limestone Bedrock

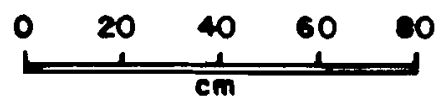

FIGURE 5. Profiles of west and south walls of test pit in the limestone masonry building at Site 41PS109. 
deepest part of the dugout measures $65 \mathrm{~cm}$, while the opposite end is at ground level. The floor of this feature is of leveled, natural limestone bedrock.

Within the structure, a scatter of limestone rubble and a small amount of wind-deposited sand was observed. The limestone rubble originated from the friable, jointed limestone bedrock walls of the dugout due to the processes of natural weathering and frost action, and is not considered to have cultural significance. No artifacts were observed within the structure. It is assumed that this dugout was at one time covered by a superstructure of some type, possibly a frame storage shed. There is no evidence remaining of this superstructure and no indication of its use, although such structures may have been used for storage of equipment or possibly even explosives.

Site 41PS109 is limited on the west by the right-of-way fence, on the north and south by a break in the bedrock slope, and on the east by the original road cut. The site lies approximately $0.25 \mathrm{mile}$ from Site 41PS344 (Fig. 1) and there is no direct physical connection between them. They are separated by a steep arroyo and intervening mountain spur.

The third location investigated is near the north end of the Historic District and to the east of the existing highway (Fig. 1). The cultural feature here consists of two circular concrete slabs. One of the slabs lies within the existing right-of-way and the other is adjacent to it but outside of the right-of-way. The slabs are approximately 5 meters in diameter and are presumed to have formed the foundations for structures of some type. However, no other evidence of these structures remains. No other cultural remains were observed at this location. This feature has not been recorded as an archaeological site and has not been issued a site number. 


\section{CONCLUSIONS AND RECOMMENDATIONS}

Site 41PS344 is believed to represent a small early twentieth century dump for domestic refuse, probably dating from circa 1915. Domestic refuse was discarded there by Mexican and Mexican-American mine workers and their families. The refuse was discarded in an area where bedrock is exposed on the surface. Thus the refuse has been subject to influences producing disturbance of the cultural remains such as wind, water, and scavenging animals such as local dogs. There is no stratified sequence of deposits, only a surface scatter of disturbed material. No further work is recommended at this site, which lies outside of the Shafter Historic Mining District.

Site 41PS109 represents a small roughly coursed, double wall masonry structure with rubble fill and mud mortar. The size might suggest that this was not a residence. However, the use to which this structure was put still remains a question to be answered. The sheet-metal stove was affixed to the bedrock floor with spikes, indicating that it was uncovered in situ and served to provide a source of heat for the structure rather than, say simply having been put there for storage and abandoned. The associated dugout was probably used as the foundation for a storage structure of some type.

The rubble fill and mud mortar which formed the walls of the masonry building incorporated domestic refuse such as broken glass and ceramic fragments. Since the mud used for mortar may have been brought to the site from another location, these items do not provide clues to the structure's function. The mansonry ruin and associated dugout are thought to date from circa 1900 and may reveal significant archaeological data on the Mexican and Mexican-American mine laborers of this early Texas mining district. Site 41PS109 relates directly to the early phase of the activities at the Shafter Historic District. It is the only structure to have undergone archaeological testing in the Historic District and provides us with an idea of the potential of structures of this type. 
Further work is recommended for Site 41PS109. It is recommended that this work be oriented toward revealing floor features, defining the entrance area, and clearing rubble from the exterior walls to provide data sufficient to make elevation drawings of all walls. It is hoped that additional work will provide data illuminating the function of this structure. It is suggested that all deposits outside of but in the area of the masonry structure and the dugout be excavated to bedrock, as well as a complete excavation of those deposits within the masonry structure.

The remaining location investigated in this testing operation contains the concrete slabs, one lying within the highway right-of-way and one located outside of it. These slabs are believed to date from the period of 1920 to 1930 and probably served as the foundations for structures of some sort. No associated cultural material was observed and there is no other extant evidence regarding the nature of these structures. No further investigation is recommended at this locality, and the features have not been given an archaeological site number. 